\title{
Antihyperglycemic Studies on the Leaf Extract and Active Fractions of Newbouldia laevis (Bignoniaceae)
}

\author{
Chinyelu C. Osigwe1, Peter A. Akah ${ }^{1}$, Chukwuemeka S. Nworu ${ }^{1 *}$, Theophine C. Okoye1, \\ Michel K. Tchimene ${ }^{2}$ \\ ${ }^{1}$ Department of Pharmacology and Toxicology, Faculty of Pharmaceutical Sciences, University of Nigeria, \\ Nsukka, Nigeria \\ ${ }^{2}$ International Centre for Ethnomedicine and Drug Development, Nsukka, Nigeria \\ Email: "Chukwuemeka.nworu@unn.edu.ng
}

Received 9 September 2015; accepted 21 November 2015; published 24 November 2015

Copyright (C) 2015 by authors and Scientific Research Publishing Inc.

This work is licensed under the Creative Commons Attribution International License (CC BY). http://creativecommons.org/licenses/by/4.0/

c) (i) Open Access

\section{Abstract}

Optimal control of chronic hyperglycemia prevents both micro and macro vascular complications-a leading cause of morbidity and mortality in diabetic subjects. This study was undertaken to give credence to the traditional use of Newbouldia laevis leaves in the treatment of diabetes mellitus (DM). Dichloromethane-methanol (1:1) extract (DME) of $N$. laevis leaves was prepared by cold maceration. Separation of DME into column chromatographic fractions yielded the $n$-hexane fraction (HF), ethylacetate fraction (EF) and methanol fraction (MF). The extract and fractions were evaluated for antihyperglycemic activity in alloxanized diabetic rats. The results showed that the oral administration of extract and fractions $(250,500,1000 \mathrm{mg} / \mathrm{kg})$ caused a significant $(P<0.5)$ and dose-dependent reduction in blood glucose level in diabetic rats. The hypoglycemic potency after $24 \mathrm{~h}$ was in the order MF (methanol fraction; 56.31\%) > DME (dichloromethane/methanol extract; $36.19 \%$ ) > EF (ethylacetate fraction; 20.70\%) > HF (n-hexane fraction; 10.09. The methanol fraction, which showed the highest potency in oral glucose tolerance test (OGTT), was further separated into column chromatographic sub-fractions $-F_{1}, F_{2}, F_{3}$ and $F_{4}$ fractions. These sub-fractions were evaluated for antihyperglycemic activity. Sub-fractions $F_{1}, F_{2}$ and $F_{3}(1000 \mathrm{mg} / \mathrm{kg})$ did produce significant $(P>0.05)$ reduction in blood glucose level after $24 \mathrm{~h}$. Sub-fraction $F_{4}(50,100,200 \mathrm{mg} / \mathrm{kg})$, however caused a significant $(P<0.05)$ and dose-dependent reduction in blood glucose level. The reduction at $200 \mathrm{mg} / \mathrm{kg}$ dose of $F_{4}(74.57 \%)$ was significantly $(P<0.05)$ higher than that of glibenclamide $(58.04 \%)$. These findings suggest that leaf extract and fractions of Newbouldia laevis possess antihyperglycemic activities and can be the basis for the folk use $N$. laevis in management of diabetes mellitus.

${ }^{*}$ Corresponding author.

How to cite this paper: Osigwe, C.C., Akah, P.A., Nworu, C.S., Okoye, T.C. and Tchimene, M.K. (2015) Antihyperglycemic Studies on the Leaf Extract and Active Fractions of Newbouldia laevis (Bignoniaceae). Pharmacology \& Pharmacy, 6, 518-532. http://dx.doi.org/10.4236/pp.2015.611054 


\section{Keywords}

\section{Newbouldia Laevis, Antihyperglycemic, Diabetes Mellitus, Blood Glucose, Alloxan, Hypoglycemia}

\section{Introduction}

Diabetes Mellitus (DM) is the commonest serious, complex and multifarious group of metabolic disorders of multiple etiology that disturbs carbohydrate, fat and protein metabolism, characterized by chronic hyperglycemia as a result of relative or absolute lack of insulin or mounting resistance to its action [1]. Chronic hyperglycemia gives rise to the risk of microvascular (retinopathy, nephropathy and neuropathy) and macro vascular (ischaemic heart disease, stroke and peripheral vascular disease) damage with attendant reduction in life expectancy and diminished quality of life [2]. The world prevalence of diabetes among the adult population aged 20 years to 79 years in 2010 was $6.4 \%$ affecting 285 million adults and expected to rise to $7.7 \%$ and 439 million adults by the year 2030 [3]. A report by the International Diabetes Federation said that more than 371 million people (8.3\%) of the world's population had diabetes in 2012 [4]. This dramatic increase is noted to be more in developing countries particularly in Sub-Saharan Africa and Asia [5] as a result of on-going quest in adopting "western life style" and diet. The currently available orthodox medicines to control hyperglycemia in DM management include: "insulins, insulin secretagogues (sulfonylureas, meglitinides), insulin sensitizers (biguanides, thiazolidinedione), agents that enhance incretin secretion and action (incretin analogues, incretin mimetics, dipeptidyl peptidase IV (DPP-IV) inhibitors), agents that decrease gastrointestinal glucose absorption (alpha glucosidase inhibitors, alpha amylase inhibitors, sodium-glucose co-transporter (SGLT-1) selective inhibitors), agents that promote renal glucose excretion (sodium-glucose co-transporter (SGLT-2) inhibitors) and others (amylin analogue, bile acid sequesterants, bromocriptine) [6]-[8]. Despite the knowledge of the pathological processes involved in causation/progression of the disease and the wide range of therapeutic agents designed to fight hyperglycemia, the statistical projections are still alarming and the stability of communities is being threatened. Alternative strategies to the current pharmacological options of DM management are therefore urgently needed [9] to manage this crippling global health problem. The plant kingdom has become a target for the search of biologically active lead compounds for complementary/alternative management of diabetes mellitus. Medicinal plants are noted to play an important role in the management of diabetes. The effect of these plants may delay the development of diabetic complications and correct the metabolic abnormalities [10]. Similarly, it has been reported that some bioactive drugs isolated from plants showed antidiabetic activity with more efficacy than hypoglycemic agents used clinically [11]. Ethnobotanical and ethnopharmacological surveys report that more than 1200 plants are being used in many ethnic societies around the world in traditional medicine for their alleged hypoglycemic activity [12]-[15] and Newbouldia laevis (Bignoniaceae) is one of such plants.

The morphology, habitat and cultivation of Newbouldia laevis have been described [16]-[18]. In some parts of Southeastern Nigeria, it is usually planted at the grave to mark the position of the head of the deceased. This plant popularly known as boundary tree, chieftaincy tree, fertility plant or tree of life is locally called "Ogirisi" in Igbo, "Akoko" in Yoruba and "Aduruku" in Hausa languages [19]. The leaves, stem bark, roots and root bark of $N$. laevis have been reported to have versatile applications and are used in more than 25 medical purposes throughout the tropical Africa [17], including but not limited in Nigeria, Togo, Senegal, Ghana, Congo, Cote de Voire, and Cameroun. Some of the documented medical uses include in the folk treatment of fevers (including yellow fever), malaria, stomach ache, cough, sexually transmitted infections, skin infections, tooth ache, breast cancer, constipation, pain (pelvic pain in females, chest pain, ear ache), gonococcal orchitis, elephantiasis, sorefeet, ulcer, epilepsy, convulsion, migraine, sickle cell anaemia, as a febrifuge, as a vermifuge, in female reproductive healthcare (fibroids, infertility, hemorrhage), as aphrodisiacs, eye problems, snake bites, wound healing, diabetes, arthritis, rheumatism and other inflammatory conditions [20]-[28].

Pharmacological studies on extracts of different parts of $N$. laevis have revealed the antioxidant [29], free radical scavenging [30], antimicrobial [31] [32], antimalarial [33], sedative and anticonvulsant [34]-[36], analgesic, antinociceptive and antiinflamatory [37] [38], hepatoprotective [29], anticancer [39], uterine contraction [40], wound healing and antiulcer [41], antisickling [42], hypoglycemic [43], antihypertensive [44] [45], entomocide [46] activities among others. Scientific reports on the phytochemical constituents of different plants of 
the plant revealed the presence of alkaloids, phenylpropaniod glycosides, flavonoids, tanins, saponins, phenols, essential oils, terpenoids, triterpenoids, quinoids, ceramides among others [29] [47]-[49].

In Southeastern and Midwestern Nigeria, a hydro-alcoholic decoction of $N$. laevis leaves has been used in folk medicine for the management of diabetes mellitus. Previously, there are preliminary reports on the antihyperglycaemic and antidiabetic studies which were on the crude extract of the leaves [4] [43] [50] [51]. In this study, we evaluated the crude leaf extract of $N$. laevis and its solvent fractions for antihyperglycemic activity in alloxan diabetic rats (acute study) in order to explore the fraction(s) that has/have the active principle(s) responsible for the antihyperglycemic activity.

\section{Materials and Methods}

\subsection{Collection and Identification of Plant Materials}

Mature fresh leaves of Newbouldia laevis were collected from Igbo-Ukwu, Aguata L.G.A of Anambra State, South-Eastern Nigeria. The whole plant was identified and classified by Mr. J.M.C. Ekekwe, a plant analyst of the Department of Botany, University of Nigeria, Nsukka. The leaves were washed to remove contaminants, air-dried under shade and thereafter pulverized into a coarse powder.

\subsection{Experimental Animals}

Adult rats (150 - $250 \mathrm{~g})$ and mice (15 - $30 \mathrm{~g}$ ) of both sexes bred in the laboratory animal facility of the Department of Pharmacology and Toxicology, University of Nigeria, Nsukka were used for the study. The animals were kept in still cages within the facility and fed with standard livestock feeds and allowed free access to water. The animals were allowed 14 days acclimatization period on transfer to the research area before the studies. All animal experiments were in accordance to our institutional ethics guidelines and in compliance with the National Institute of Health and Guide for care and use of Laboratory Animals (Pub No. 85 - 23 revised).

\section{Preparation of extract:}

The air dried and powdered material (5 kg) was macerated in a mixture of dichloromethane/methanol (1:1) for 48 hours and filtered. Removal of solvent in-vacuo in a rotary evaporator provided an organic extract of $14.2 \%$ yield (710 g) and labeled DME.

\subsection{Acute Toxicity Test $\left(L D_{50}\right)$}

The acute toxicity/lethality $\left(\mathrm{LD}_{50}\right)$ of DME in mice was determined using the method described by Lorke (1983) [52]. Adult albino mice of both sexes with a fasting body weight of $15-30 \mathrm{~g}$ were used. The $\mathrm{LD}_{50}$ for the oral and intra-peritoneal routes were determined. The study was carried out in two stages. In the first stage 9 mice were randomly divided into 3 groups $(\mathrm{n}=3$ ) and treated orally with the extract at 10,100 and $1000 \mathrm{mg} / \mathrm{kg}$ dose levels. The animals were observed for $24 \mathrm{~h}$ and the number that died in each group was recorded. Based on this, the doses for the second stage were selected. In this stage, 3 groups (as no animal died in the initial stage) of mice $(n=1)$ were treated with the extract at 1600,2900 and $5000 \mathrm{mg} / \mathrm{kg}$ dose levels respectively. The $\mathrm{LD}_{50}$ was calculated as the geometric mean of the minimum lethal dose and the maximum non-lethal dose. The same procedure was carried out for the intra-peritoneal route using a separate group of mice.

\subsection{Solvent-Guided Fractionation of DME and Bioactivity-Guided Studies}

The crude DME extract (500 g), was subjected to solvent guided fractionation in a silica gel (60 - 200 mesh size) column and successively eluted with n-hexane, ethylacetate and methanol in order of increasing polarity to yield n-hexane fraction (HF; $35.7 \mathrm{~g} ; 7.14 \%$ ), ethylacetate fraction (EF; $181.9 \mathrm{~g} ; 36.38 \%$ ) and methanol fraction (MF; $245.5 \mathrm{~g} ; 49.09 \%)$. The fractions were concentrated using rotary evaporator $\left(40^{\circ} \mathrm{C}-50^{\circ} \mathrm{C}\right)$ under reduced pressure. The DME and fractions HF, EF, and MF were subjected to phytochemical analysis for identification of phytoconstituents and biological activity studies. The antihyperglycemic effect on alloxan diabetic rats was used to determine activity. Methanol fraction (MF) which showed the most potent antihyperglycemic activity was subjected to further fractionation. About $150 \mathrm{~g}$ of MF was fractionated by column chromatographic methods using gradient elution with n-hexane/ethylacetate (7:3) [53] to obtain twenty five (25) sub-fractions of MF. Thin layer chromatography (TLC) was employed to pull the column chromatographic fractions together on the basis of the $R f$ values of the similar spots to obtain four sub-fractions: $F_{1}(24.3 \mathrm{~g} ; 16.2 \%), F_{2}(27.9 \mathrm{~g} ; 18.6 \%), \mathrm{F}_{3}$ (20.3 g; 
13.5\%) and $\mathrm{F}_{4}$ (73.8 g; 49.2\%) which were screened further. The sub-fractions were subjected to antihyperglycemic activity studies on alloxan diabetic rats and $\mathrm{F}_{4}$ was significantly $(P<0.05)$ the most potent antihyperglycemic fraction. Sub-fraction $\mathrm{F}_{4}$ was subjected to phytochemical analysis to determine the phytoconstituents present.

\subsection{Phytochemical Analysis}

Preliminary phytochemical tests were carried out on the extract, HF, EF, MF and $\mathrm{F}_{4}$ using standard protocols [54], to qualitatively detect the presence, absence and relative amount of phytoconstituents.

\subsection{Hypoglycemic Activity Test}

Induction of diabetes: Diabetes was induced in adult albino rats of both sexes by a single intravenous injection of freshly prepared alloxan monohydrate (65 mg/kg) in $0.9 \%$ saline [53] [55]. Glucose solution (50\%) was used to prevent the initial hypoglycemia caused by alloxan monohydrate [55] [56]. Blood samples were collected after 3 days from overnight fasted animals through the tail vein and blood glucose level was estimated using commercially available Accu-check Active (Roche Diagnostics) glucometer. Blood glucose levels above 250 $\mathrm{mg} / \mathrm{dl}$ [56] were considered diabetic and selected for the study.

The diabetic animals were randomly divided into 14 groups $(n=5)$. Groups 1 - 12 received oral administration of DME, HF, EF, and MF at graded dose levels of 250, 500, and $1000 \mathrm{mg} / \mathrm{kg}$. Group 13 received glibenclamide (Daonil $^{\mathrm{TM}}$ Sanofi-Aventis, Nigeria) (5 mg/kg) [43] as a reference drug. Group 14 received 3\% tween 80 $(5 \mathrm{ml} / \mathrm{kg}$ ) and served as negative control group. Blood samples were withdrawn through the tail vein at 0 (pre-treatment) and at 3, 6, 9, 12 and $24 \mathrm{~h}$ post treatment. The blood glucose levels were determined using the glucometer and percentage reductions in blood glucose levels were calculated relative to pretreatment values [57] [58].

\subsection{Hypoglycemic Activity Test of Sub-Fractions of Methanol Fraction $\left(F_{1}, F_{2}, F_{3}, F_{4}\right)$}

Six groups of diabetic rats $(n=5)$ were used. Groups $1-3$ received $1000 \mathrm{mg} / \mathrm{kg}$ of $F_{1}, F_{2}$ and $F_{3}$ respectively. Groups 4-6 received 50, 100 and $200 \mathrm{mg} / \mathrm{kg}$ respectively of $F_{4}$. Blood samples were withdrawn and blood glucose levels were measured as described, at 0 (pretreatment), 3, 6, 9, 12 and $24 \mathrm{~h}$ post treatment. The percentage reductions in blood glucose levels were calculated relative to pretreatment values.

\subsection{Effect of Methanol Fraction (MF) on Fasting Blood Glucose Levels of Normoglycemic Rats}

Twenty five adult albino rats of both sexes were fasted overnight and randomly divided into 5 groups $(\mathrm{n}=5)$. Groups 1 - 3 received oral administration of MF (250, 500, $1000 \mathrm{mg} / \mathrm{kg}$ respectively). Group 4 received glibenclamide $(5 \mathrm{mg} / \mathrm{kg})$ as reference drug. Group 5 received 3\% tween $80(5 \mathrm{ml} / \mathrm{kg})$ and served as negative control group. The basal fasting blood glucose level was measured before treatment as described before and at 30,60, 120 and 240 min post-treatment. The percentage reductions in blood glucose levels were calculated relative to pretreatment values.

\subsection{Oral Glucose Tolerance Test (OGTT)}

Twenty five adult rats of both sexes were fasted for $16 \mathrm{~h}$ but allowed free access to water. They were randomly divided into five groups $(\mathrm{n}=5)$. Groups 1 - 3 received oral administration of MF $(250,5001000 \mathrm{mg} / \mathrm{kg}$ respectively). Groups 4 and 5 received glibenclamide $(5 \mathrm{mg} / \mathrm{kg})$ and $3 \%$ tween $80(5 \mathrm{ml} / \mathrm{kg})$ respectively. After $60 \mathrm{~min}$, the animals were fed with glucose $(4 \mathrm{~g} / \mathrm{kg}$ ) [57] [59]. The blood glucose levels in each group were measured as described at 0 (before treatment) and at 30, 60, 120, 180 and 240 min after glucose challenge. The percentage change in blood glucose level was calculated relative to 0 min [57].

\subsection{Statistical Analysis}

The values obtained were analysed using one way analysis of variance (ANOVA) (SPSS Version 20) software and presented as mean \pm SEM. Differences between means were considered significant at $P<0.05$ (LSD post hoc test). 


\section{Results}

\subsection{Result of Phytochemical Analysis}

The preliminary phytochemical tests on the extract and fractions gave positive results of alkaloids, flavonoids, steroids, saponins, tanins, terpenoids, carbohydrates, proteins, oils, acidic compounds, reducing sugars and resins (Table 1).

\subsection{Acute Toxicity $\left(\mathrm{LD}_{50}\right)$}

The oral $\mathrm{LD}_{50}$ of the crude DME was $>5000 \mathrm{mg} / \mathrm{kg}$ and was considered safe as no animal died at $5000 \mathrm{mg} / \mathrm{kg}$. The intraperitoneal (i.p.) $\mathrm{LD}_{50}$ was calculated to be $3807.9 \mathrm{mg} / \mathrm{kg}$. The maximum non-lethal dose was 2900 $\mathrm{mg} / \mathrm{kg}$ and the minimum lethal dose was $5000 \mathrm{mg} / \mathrm{kg}$.

\subsection{Hypoglycaemic Effect of Extract and Fractions}

Administration of the extract (DME) and fractions (HF, EF, MF) produced significant $(P<0.05)$ lowering of mean blood glucose level to varying extent in diabetic rats at all the dose levels (Figures 1-4). The antihpergly-

Table 1. Result of phytochemical analysis.

\begin{tabular}{|c|c|c|c|c|c|}
\hline \multirow{2}{*}{ Phytoconstituents } & \multicolumn{5}{|c|}{ Relative abundances } \\
\hline & DME & $\mathrm{HF}$ & $\mathrm{EF}$ & MF & $\mathrm{F}_{4}$ \\
\hline Alkaloids & ++ & - & ++ & +++ & +++ \\
\hline Flavonoids & ++ & - & + & +++ & +++ \\
\hline Glycosides & + & - & - & - & - \\
\hline Steroids & ++ & +++ & + & + & - \\
\hline Saponins & + & - & - & ++ & +++ \\
\hline Tannins & ++ & - & ++ & ++ & +++ \\
\hline Carbohydrates & + & - & ++ & ++ & + \\
\hline Proteins & + & - & + & ++ & - \\
\hline Oils & + & +++ & - & - & - \\
\hline Acidic compounds & + & + & + & ++ & + \\
\hline Reducing sugars & - & + & + & +++ & + \\
\hline Resins & + & ++ & ++ & ++ & +++ \\
\hline Terpenoids & ++ & ++ & + & + & - \\
\hline
\end{tabular}

Key: $(-) \rightarrow$ absent; $(+) \rightarrow$ present in small amount; $(++) \rightarrow$ present in moderate amounts; $(+++) \rightarrow$ abundantly present.

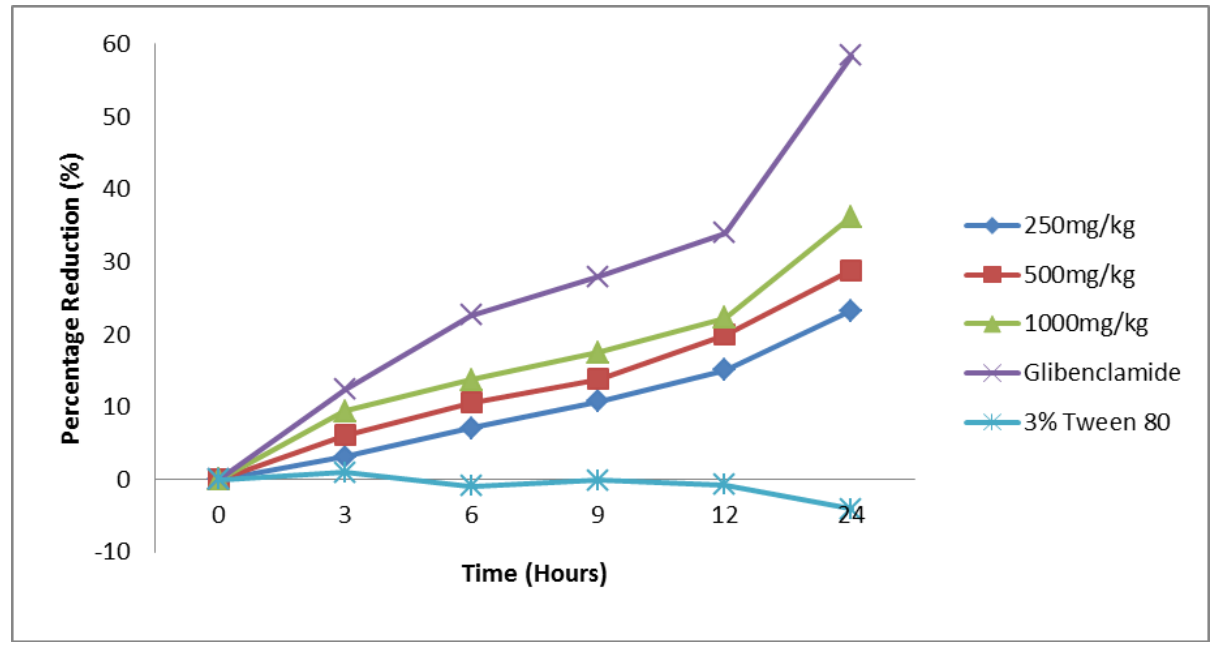

Figure 1. Effects of Dichloromethane/Methanol (DME) extract of N. laevis on diabetic rats. 


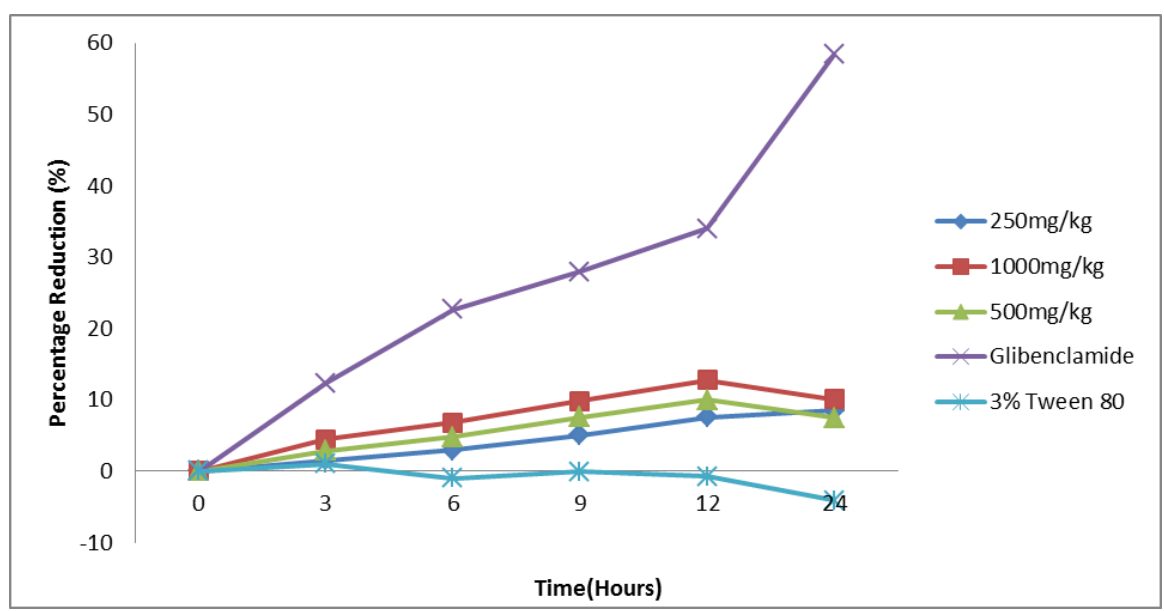

Figure 2. Effects of n-hexane fraction (HF) of $N$. laevis on diabetic rats.

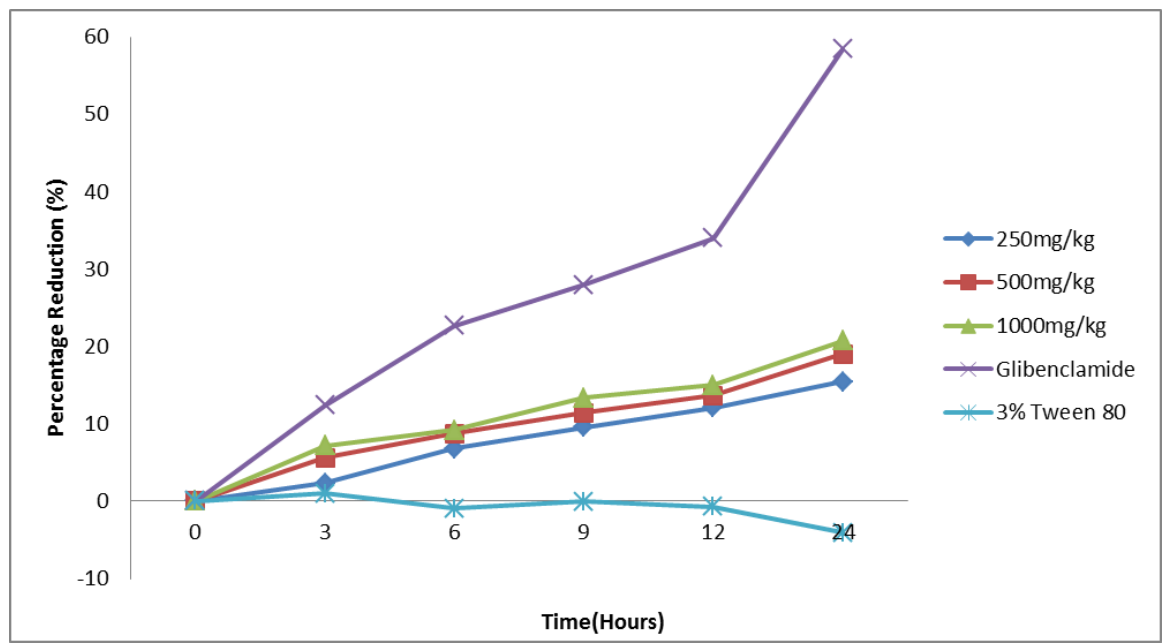

Figure 3. Effects of ethylacetate fraction (EF) of $N$. laevis on diabetic rats.

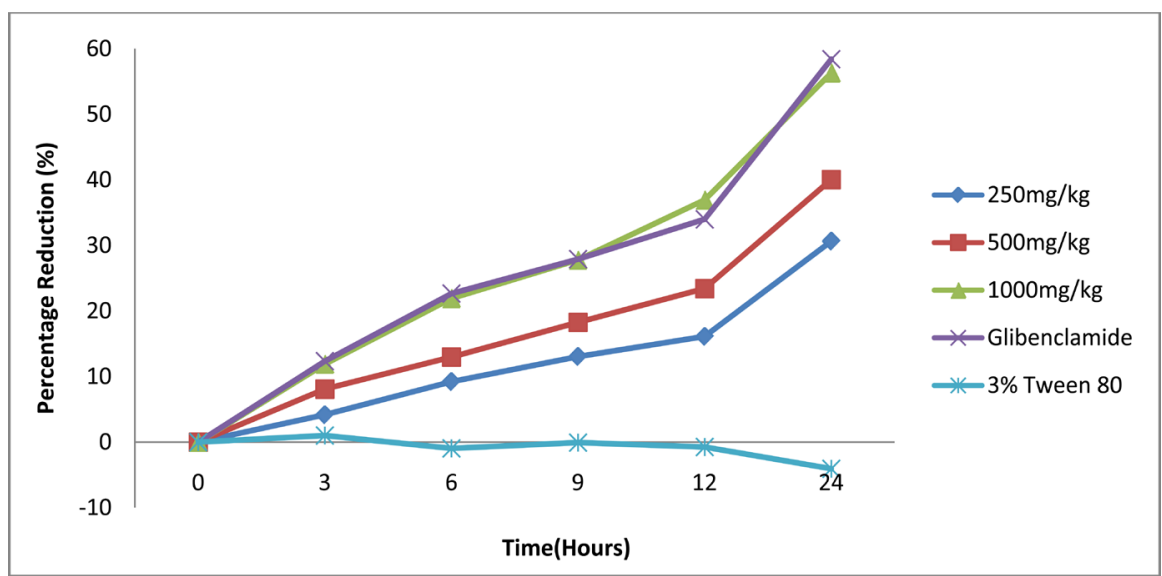

Figure 4. Effect of methanol fraction (MF) of $N$. laevis on diabetic rats.

cemic effect was observed to be dose-related and the order of potency was MF $>$ DME $>$ EF $>$ HF (Figures 1-4). The antihyperglycemic effect of MF (1000 mg/kg) was comparable to that of the reference drug. The percentage reduction in blood glucose levels were calculated relative to pretreatment values. 


\subsection{Hypoglycaemic Effect of Sub-Fractions}

Fractions $F_{1}$ and $F_{2}$ at the highest dose of $1000 \mathrm{mg} / \mathrm{kg}$ could not lower the blood glucose levels in alloxan diabetic rats after $24 \mathrm{~h}$ when compared to the control $(P<0.05)$. Fraction $\mathrm{F}_{3}$ showed only weak $(7.52 \%)$ reduction in blood sugar at the $6 \mathrm{~h}$ which could not be sustained at the 12 and $24 \mathrm{~h}$ time points. However, fraction (50, 100, $200 \mathrm{mg} / \mathrm{kg}$ ) showed significant dose-related hypoglycemic activity (Figure 5). There was a marked decrease in blood glucose level of diabetic rats at $3 \mathrm{~h}$ time point; an effect that was sustained up to the $24 \mathrm{~h}$. The reduction in blood glucose level of diabetic rats that received $50 \mathrm{mg} / \mathrm{kg}$ of $\mathrm{F}_{4}$ was comparable with the glibenclamide treated group at $6 \mathrm{~h}, 9 \mathrm{~h}$ and $12 \mathrm{~h}$ time points. Group of diabetic rats treated with $100 \mathrm{and} 200 \mathrm{mg} / \mathrm{kg}$ of $\mathrm{F}_{4}$ showed significantly $(P<0.05)$ higher reduction in blood glucose level at $6 \mathrm{~h}, 9 \mathrm{~h}$ and $12 \mathrm{~h}$ time points when compared to the reductions in groups that received glibenclamide. Maximum reduction of blood sugar $(74.57 \%)$ was observed at a dose of $200 \mathrm{mg} / \mathrm{kg}$ of $\mathrm{F}_{4}$ after $24 \mathrm{~h}$ which was significantly $(P<0.05)$ higher than the reductions produced by glibenclamide treated group (58.04\%) at the same time point (Figure 5).

\subsection{Effect of Methanol Fraction (MF) on Fasting Blood Glucose Level of Normoglycemic Rats}

Oral administration of methanol fraction (MF) at the three doses tested showed significant $(P<0.05)$ reduction in fasting blood glucose of normoglycemic rats at $2 \mathrm{~h}$ time point compared to the mean blood glucose level in the negative control group. The groups of rats that received 500 and $1000 \mathrm{mg} / \mathrm{kg}$ of MF showed a significant dose dependent reduction at $1 \mathrm{~h}$ and $2 \mathrm{~h}$ time points. The methanol fraction $(250 \mathrm{mg} / \mathrm{kg})$ did not reduce fasting blood glucose significantly $(P>0.05)$ at $1 \mathrm{~h}$ time point. The reduction at $2 \mathrm{~h}$ time point $(3.17 \%)$ was however higher than that of $500 \mathrm{mg} / \mathrm{kg}(2.94 \%)$ although the difference was not significant $(P>0.05)$. The glibenclamide treated group however showed a significant reduction in the mean fasting blood glucose at all the time points (Figure 6). The fasting blood glucose level of all the rats treated with the methanol fraction returned to basal levels at $3 \mathrm{~h}$ time point. Rats treated with glibenclamide as standard oral hypoglycemic drug remained below basal level at $3 \mathrm{~h}$ time point.

\subsection{Effect of the Methanol Fraction (MF) on Oral Glucose Tolerance Test in Normoglycemic Rats}

Following oral administration of glucose, post-prandial blood glucose escalated to $104 \%$ in the control (untreated) group at $30 \mathrm{~min}$ post-treatment peak. Pre-treatment with MF (250, 500, $1000 \mathrm{mg} / \mathrm{kg})$ suppressed this sudden glucose excursion by $43.26 \%, 39.12 \%, 24.50 \%$ respectively and produced a significant $(P<0.05)$ and progressive reduction in blood glucose level up to 180 min when compared to the untreated group (Figure 7). The MF (1000 mg/kg) treated group suppressed postprandial hyperglycaemia $(24.50 \%)$ better than the glibenclamide treated group (28.61\%) $(P<0.05)$. The blood glucose level of MF $(500,1000 \mathrm{mg} / \mathrm{kg})$ treated groups remained below basal levels (pre-treatment values) between 120 and 150 min post treatment. The effect was comparable to the blood sugar reductions produced by glibenclamide treated group $(P<0.05)$ (Figure 7). However the blood glucose level in all the groups returned to pre-treatment values after $180 \mathrm{~min}$.

\section{Discussion}

Hyperglycemia is the defining feature of diabetes mellitus. Chronic hyperglycemia is associated with both microvascular and macrovascular complications in patients with diabetes [2], both of which are responsible for increased morbidity and mortality in diabetic subjects. Chronic hyperglycemia is directly and proportionately related to glycosylation of haemoglobin and lipid peroxidation, both of which are markers that herald the onset of diabetic complications [60]. Evidence has shown that tight and optimal blood glucose control eliminates diabetic complications [61]. The global incidence of the disease is geometrically rising to pandemic proportions. The bane of diabetes management has been to keep both short-term and long-term blood glucose levels optimized within acceptable limits in order to prevent or reduce these complications. This can only be achieved by tightly controlling fasting blood glucose levels as well preventing post prandial glucose excursions [62]. The later has been recognised lately as a better marker of glycaemic control than fasting blood glucose since glycation of haemoglobin is primarily favoured by post prandial hyperglycaemia [63]. Plasma glycated haemoglobin (HbA1c) level is an index of glycaemic control [60]. 


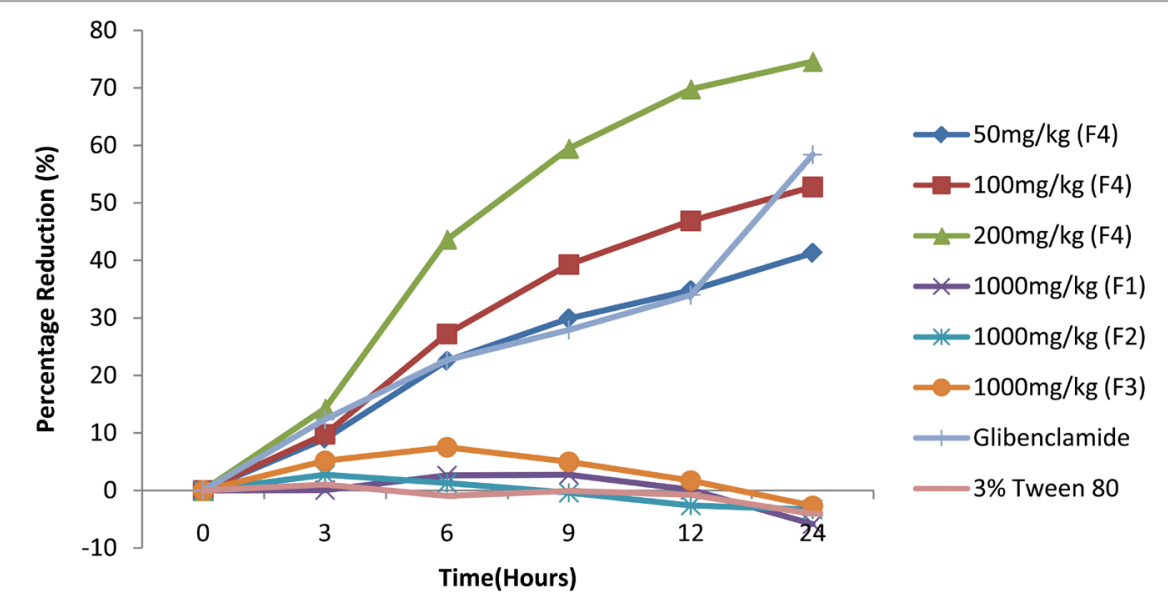

Figure 5. Effect of sub-fractions of methanol fraction of $N$. laevis on diabetic rats.

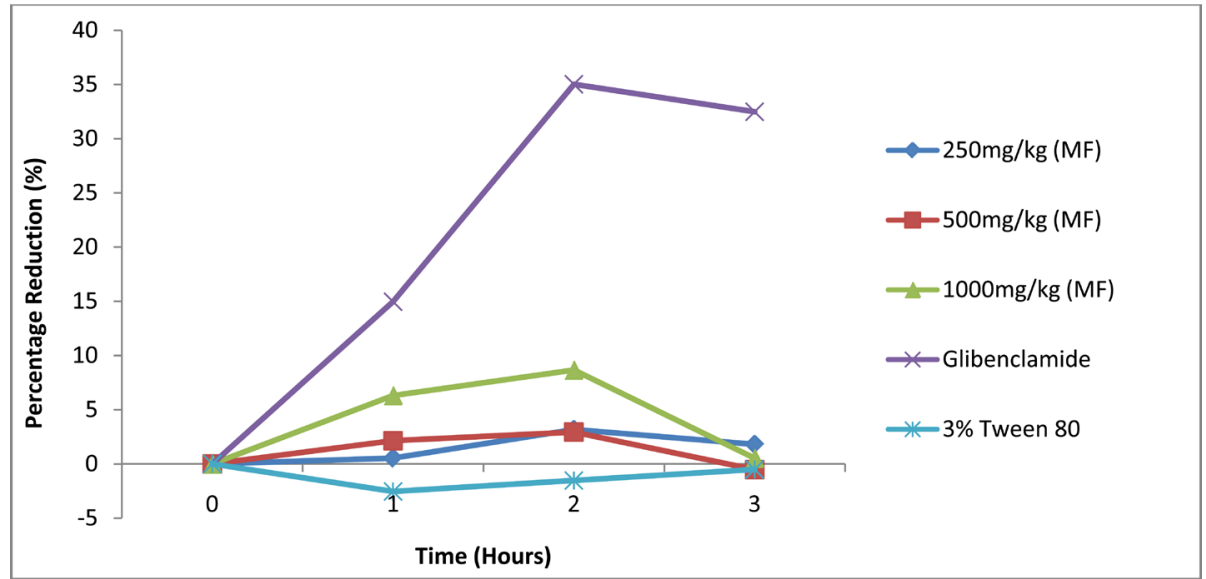

Figure 6. Effect of methanol fraction (MF) of $N$. laevis on fasting blood glucose level of normoglycemic rats.

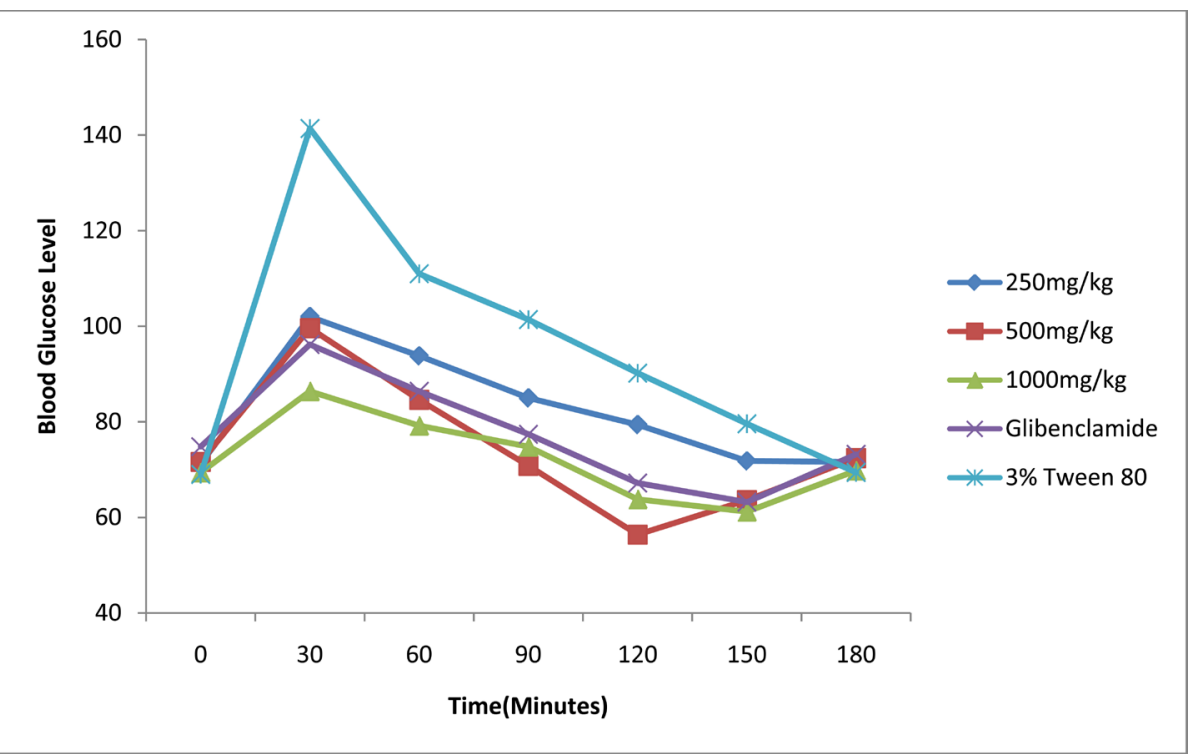

Figure 7. Effects of methanol fraction (MF) of $N$. laevis on oral glucose tolerance on non-diabetic rats. 
Many of the available orthodox hypoglycaemic medications have not effectively addressed this global health problem. The reasons include affordability, accessibility, side-effects, acceptability, use restrictions in certain populations, and limitation of the agents in addressing underlying biochemical and pathological aberrations associated with the disease among many other reasons. Phytomedicines as an alternative have proven to be relatively safer, cheaper, more available and acceptable among the cultural society where they are found. Phytotherapy have demonstrated at least in animal models to prevent and/or halt the disease at different points of its natural history [64] [65].

Prior to evaluating the effectiveness of antidiabetic plants, World Health Organization (WHO) advocates that their safety be evaluated in order to standardize their use. Marles and Farnsworth (1994) [66] earlier noted that about one third of medicinal plants used in traditional ethnomedical treatment of diabetes mellitus are toxic. Therefore, the oral acute toxicity of the dichloromethane-methanol (1:1) leaf extract of Newbouldia laevis was evaluated and found to be greater than $5000 \mathrm{mg} / \mathrm{kg}$ body weight. This finding agrees with previous reports on the $\mathrm{LD}_{50}$ of the leaf extract [43]. Toxicological assessment and safety of various parts of $N$. laevis has been reported [29] [49] [67]. Their findings suggest a high safety profile of $N$. laevis extracts and could be suitable for use in management of chronic diseases such as diabetes mellitus.

Alloxan is known to induce free radical generation of which the pancreatic beta cells are particularly vulnerable [68] leading to massive destruction of insulin secreting cells and subsequent hyperglycemia. In the present study, it was observed and demonstrated that oral administration of extract and fractions of $N$. laevis leaf exhibited effective and dose dependent reduction in blood glucose levels of alloxan diabetic rats and could have possibly reversed the effect of alloxan in causing and maintaining hyperglycemia in animal studies. Previous reports on antihyperglycemic effects of plant extracts on alloxan diabetic animal models favour regeneration of islet beta cells as the primary mechanism of recovery of alloxan injected animals [68]. The reported antioxidant and free radical scavenging properties of $N$. laevis extracts [30] [45] [69] [70] may have contributed to the recovery of the pancreatic beta islet cells and restoration of its secretory function. Methanol fraction slightly lowered the fasting blood glucose level of normoglycemic rats suggesting weak insulin secretagogue activity in nonglycemic state. The methanol fraction however, demonstrated a significant improvement in oral glucose tolerance in glucose fed hyperglycaemic non-diabetic rats which was comparable to that of the standard drug glibenclamide. This may suggest glucose dependent insulinotropic and insulinomimetic properties of the methanol fraction [10]. Inhibition of intestinal sodium-glucose co-transporter (SGLT 1) and/or inhibition of renal glucose reabsorption (SGLT 2) may contribute to the observed effects [71].

Although this study was not designed to investigate the antihyperglycemic mechanism of action of the extract and fractions in hyperglycemic non-diabetic and alloxan diabetic rats, a number of possible mechanisms (based on phytochemistry result) that may augment glucose disposal could help to explain the result of this study. Several phytoconstituents such as alkaloids, steroids, carbohydrates, glycosides, flavonoids, terpenoids, saponins, tannins, resins, peptides and amino acids, lipids, phenolics, glycopeptides and iridoids with putative antihyperglycemic activity have been reported [72] [73]. The preliminary phytochemical analysis of sub-fractions $\mathrm{f}_{4}$ (showing highest activity of $74.57 \%$ reduction) showed high levels of alkaloids, flavonoids, saponins, resins and tannins. This suggests that the observed antihyperglycemic effects of the extract and fractions could have been mediated by one or more of these phytoconstituents.

Flavonoids have been shown to possess remarkable hypoglycaemic effects which have been linked to their capacity to avoid glucose absorption or improve glucose tolerance [74]. It has been demonstrated that flavonoids act as insulin secretagogues or insulin mimetics, attenuate diabetic complications, stimulate glucose uptake in peripheral tissues and regulate the activity and/or expression of the rate limiting enzymes involved in carbohydrate metabolism [75]-[77]. Flavonoids have been reported to show potent inhibitory activity against a wide range of enzymes such as lipo-oxygenases, cyclo-oxygenases, and prevent the generation or the action of free radicals which cause tissue damage during inflammatory processes [65] [78] [79]. They are therefore potent antioxidants and could modulate the activities of various enzymes involved in blood glucose homeostasis. This may have been responsible for the observed reduction of the blood glucose level by the extract and fractions of $N$. laevis leaf in alloxan-induced diabetic rats. Recently, there were similar reports on the antioxidant activities of the ethanol leaf extract of $N$. laevis and its ability to attenuate haemoglobin glycosylation and lipid peroxidation [51]. These reported antidiabetic potentials of $N$. laevis leaf extracts could only be explained wholly or in part by the result of this study since hyperglycemia favours these enzymatically induced changes in diabetic situations. Polyphenolic compounds have been implicated in the production of incretin hormone (glucagon-like 
peptide GLP-1) [65] that appears to act through many mechanisms towards effective glucose disposal, including stimulation of insulin secretion, suppression of glucagon release, slowing of gastric emptying, improving insulin sensitivity, and reduction of food intake. In rodents and cell line experiments, GLP-1 has been shown to promote $\beta$-cell regeneration, proliferation, mass, and function [65]. There is documented evidence that polyphenols slow down glucose absorption by competitive inhibition of the intestinal brush border membrane sodium-glucose co-transporter (SGLT 1) [80] as well as inhibition of disacharidases [81]. Kolawole and Abanji (2013) [82] reported the inhibition of alpha glucosidase and alpha amylase enzymes by the ethanolic leaf extract of $N$. laevis on sucrose fed rats. Phenolic compounds are known to directly cause regeneration of alloxan damaged islet beta cells by their action as antioxidants and free radical scavengers causing restoration of pancreatic beta cell function [83].

Phlorizin-like effects of plant extracts have also been reported [84]. Phlorizin a non-selective, competitive inhibitor of sodium-glucose co transporter (SGLT-1 \& SGLT-2), is a naturally occurring phenol glycoside, first isolated from the bark of an apple tree in 1835 [85] used to enhance glucose excretion through the kidneys. Modification of chemical structure of this prototype gave more selective and more potent SGLT-2 inhibitors, most of which are C-glycosides [85]. Studies have shown that oral administration of sergiflozin, a SGLT-2 inhibitor in normal and streptozotocin induced diabetic rats, increased urinary excretion in a dose dependent manner and attenuated the increase in blood glucose level following an OGTT without stimulating insulin release [86]. Similarly, dapagliflozin, a potent SGLT-2 inhibitor caused a dose dependent reduction in blood glucose level by as much as 60\% in STZ-induced diabetic rats over a 5-hr period following oral administration [87]. These findings are consistent with the findings of this study. Obute and Adubor [88] reported that the flavonoid compound in $N$. laevis leaves is majorly quercetin which occurs naturally as glycosides [89]. Quercetin glycoside was noted to be a potential substrate for lactose phlorizin hydrolase (LPH) [89] and a similar pharmacological activity with phlorizin was suggested. Interaction of quercetin glycosides with intestinal SGLT-1 has also been reported [89] [90]. Flavonoids (quercetin glycosides), saponins (triterpenoid/ steroidal glycosides) present in the extract and fractions may have acted in the above manner to cause the observed effects.

The saponin present in the fraction may have played a role to explain the improvement in the oral glucose tolerance of normoglycemic rats pretreated with methanol fraction of $N$. laevis leaf extract in this study. In other studies, saponins have been shown to possess antihyperglycemic activities or other beneficial activities relevant in the management of diabetes. For examples, charantin, a steroidal glycoside saponin from Momordica charantia is known to possess insulin-like effects, stimulates insulin release and exhibits rat lens aldose reductase inhibitory activity [91]. Similarly, saponin isolated from Gymnema sylvestre (Gymnemic acid) exhibited marked hypoglycemic effects in animal models showing stimulation of insulin secretion and release, regeneration of pancreatic beta cells and activation of glucose metabolising enzymes [92].

Alkaloids from plant extracts are reported to show antihyperglycemic activity through a number of mechanisms that regulate glucose homeostasis. Berberine effectively inhibited the activity of disaccharidases (alpha glucosidase) and decreased glucose transport through the intestinal epithelium [93]. Berberine was also reported to show antihyperglycemic activity by promoting the secretion of glucagon-like peptide-1 [94]. Catharanthine, vindoline and vindolinine are alkaloids isolated from Catharanthus roseus with potent hypoglycemic activity [95]. Arecoline, an alkaloid isolated from Areca catechu was reported to have hypoglycemic activity in animal model [96]. Aegeline, an alkaloidal amide from the leaves of Aegle marmelos was found to possess antihyperglycemic activity with suggested $\beta_{3}$-adrenergic receptor activity [97]. Trigonelline isolated from a known hypoglycemic plant Trigonella foeum graceum could lower blood glucose level in alloxan treated diabetic rats through regeneration of new islets [98]. The $\beta$-carboline alkaloids obtained from Peganum harmala stimulates insulin secretion in a dose dependent manner [99] [100] and are known insulin secretagogues from plant sources.

\section{Conclusion}

The results of this study suggest that the extract and fractions of $N$. laevis leaves possess antihyperglycemic activity in alloxan diabetic rats. Alkaloids, flavonoids, tannins, resins and saponins may be responsible for activity. This study gave credence to the ethnomedicinal use of $N$. laevis leaves in the management of diabetes. Further work is suggested to isolate the fraction(s)/compound(s) responsible for the activity. 


\section{Conflict of Interest}

The authors report no conflict of interest. The authors alone are responsible for the conduct and writing of this manuscript.

\section{References}

[1] WHO (World Health Organization) (1999) Definition, Diagnoses and Classification of Diabetes Mellitus and Its Complications. Report of a WHO Consultation, Part 1: Diagn. Classif. Diabetes Mellitus, 1-49.

[2] Min, T.S. and Park, S.H. (2010) Therapy of Diabetes Mellitus Using Experimental Animal Models. Asian-Australasian Journal of Animal Sciences, 23, 672-679. http://dx.doi.org/10.5713/ajas.2010.90637

[3] Shaw, J.E., Sicree, R.A. and Zimmet, P.Z. (2010) Global Estimates of the Prevalence of Diabetes for 2010 and 2030. Diabetes Res. Clin. Pract, 87, 4-14. http://dx.doi.org/10.1016/j.diabres.2009.10.007

[4] International Diabetes Federation (IDF) (2012) Diabetes Atlas. 5th Edition, 2012 Update.

[5] Wild, S., Roglic, G., Green, A., Sicree, R. and King, H. (2004) Global Prevalence of Diabetes. Estimates for the Year 2000 and Projections for 2030. Diabetes Care, 27, 1047-1053. http://dx.doi.org/10.2337/diacare.27.5.1047

[6] Barnett, A.H. and Grice, J. (2011) New Mechanisms in Glucose Control. Wiley-Blackwell Publishing Ltd., Hoboken, 17-71. http://dx.doi.org/10.1002/9781118682197

[7] Handelsman, Y. (2011) Role of Bile Acid Sequestrants in the Treatment of Type 2 Diabetes. Diabetes Care, 34, S244-S250. http://dx.doi.org/10.2337/dc11-s237

[8] Verspohl, E.J. (2012) Novel Pharmacological Approaches to the Treatment of Type 2 Diabetes. Pharmacological Reviews, 64, 188-237. http://dx.doi.org/10.1124/pr.110.003319

[9] WHO (World Health Organization) (2002) WHO Launches the First Global Strategy on Traditional Medicine. Press Release WHO/38, Geneva.

[10] Mardanyans, S., Sharoyan, S., Anthonyan, A. and Zakaryan, N. (2011) Dipeptidyl Peptidase IV and Adenosine Deaminase Inhibition by Armenian Plants and Antidiabetic Drugs. International Journal of Diabetes and Metabolism, 19, 69-74.

[11] Bnouham, M., Ziyyat, A., Mekhfi, H., Tahri, A. and Legssfer, A. (2006) Medicinal Plants with Potential Antidiabetic Activity. A Review of Ten Years of Herbal Medicine Research (1990-2000). International Journal of Diabetes and Metabolism, 14, 1-25.

[12] Akah, P.A., Okoli, C.O. and Nwafor, S.V. (2002) Phytotherapy in the Management of Diabetes Mellitus. Journal of Natural Remedies, 2, 1-10.

[13] Jegede, A., Oladosu, P., Ameh, S., Kolo, I., Izebe, K., Builders, P., Yahaya, T., Okhale, S., Mustapha, B., Busu, S., Shittu, H. and Gamaniel, K. (2011) Status of Management of Diabetes Mellitus by Traditional Medicine Practitioners in Nigeria. Journal of Medicinal Plants Research, 5, 6309-6315. http://dx.doi.org/10.5897/JMPR11.643

[14] Rachid, A., Rabah, D., Farid, L., Zohra, S.F., Houcine, B. and Nacera, B. (2012) Ethnopharmacological Survey of Medicinal Plants Used in the Traditional Treatment of Diabetes Mellitus in the North Western and South Western Algeria. Journal of Medicinal Plants Research, 6, 2041-2050.

[15] Mohamed, A., Ibrahim, M.A. and Islam, M.S. (2014) African Medicinal Plants with Anti-Diabetic Potentials: A Review. Planta Medica, 80, 354-377. http://dx.doi.org/10.1055/s-0033-1360335

[16] Keay, A.R.W. (1989) Trees of Nigeria. Oxford University Press, Oxford.

[17] Arbonnier, M. (2004) Shrubs and Lianas of West African Dry Zones. CIRAD Margraf Publishers, GMBH MNHN, Corte d'voire, 194.

[18] Usman, H. and Akerele, J.C. (2007) Phytochemical and In-Vitro Antimicrobial Assay of the Leaf Extract of Newbouldia laevis. African Journal of Traditional, Complementary and Alternative Medicines, 4, 476-480.

[19] Hutchison, J. and Dalziel, J.M. (1963) Flora of West Tropical Africa. Volume II, Crown Agents for Oversea Government and Administration, London, 435-436.

[20] Burkill, H.M. (1997) The Useful Plants of West Tropical Africa. 2nd Edition, Volume 4 (Families M-R), Royal Botanic Gardens, Kew.

[21] Iwu, M.M. (2000) Handbook of African Medicinal Plants. CRC Press, Inc., London, 19.

[22] Gormann, R., Kaloga, M., Ferreira, D., Marais, J.P. and Kolodziej, H. (2006) Newbouldioside A-C Phenylethanoid Glycoside from the Stem Bark of Newbouldia laevis. Phytochemistry, 67, 805-811.

http://dx.doi.org/10.1016/j.phytochem.2006.01.016

[23] Eyong, O.K., Krohn, K., Hussain, H., Folefoc, N.G., Nkengfack, A.E., Schulz, B. and Hu, Q. (2005) New- 
bouldiaquinone and Newbouldiamide: A New Naphthoquinone-Anthraquinone Coupled Pigment and a New Ceramide from Newbouldia laevis. Chemical and Pharmaceutical Bulletin, 53, 616-619. http://dx.doi.org/10.1248/cpb.53.616

[24] Ogunlesi, M., Okiei, W., Ofor, E. and Awonuga, O. (2009) Determination of the Concentration of Zinc and Vitamin C in Oysters and Some Medicinal Plants Used to Correct Male Factor Infertility. Journal of Natural Products, 2, 89-97.

[25] Oliver-Bever, B. (1986) Medicinal Plants in Tropical West Africa. Cambridge University Press, Cambridge, 117-168. http://dx.doi.org/10.1017/cbo9780511753114

[26] Adodo, A. (2004) Nature Power: A Christian Approach to Herbal Medicine. 3rd Edition, Generation Press Limited, Lagos, 183-187.

[27] Sen, S., Chakraborty, R., De, B., Ganesh, T., Raphavendra, H.G. and Debnata, S. (2010) Analgesic and Antiinflamatory Herbs: A Potential Source of Modern Medicine. International Journal of Pharmaceutical Sciences and Research, 1, 32-44.

[28] Klotoe, J.R., Dougnon, T.V., Koudouvo, K., Ategbo, J.M., Koko, F., Akoegninou, A., Aklikokou, K., Dramane, K. and Gbeassor, M. (2013) Ethno-Pharmacological Survey on Antihemorrhagic Medicinal Plants in South of Benin. European Journal of Medicinal Plants, 3, 40-51. http://dx.doi.org/10.9734/EJMP/2013/2093

[29] Hassan, S.W., Salawu, K., Ladan, M.J., Hassan, L.G., Umar, R.A. and Fatihu, M.Y. (2010) Hepato-Protective, Antioxidant and Phytochemical Properties of Leaf Extracts of Newbouldia laevis. International Journal of PharmTech Research, 2, 573-584.

[30] Akinmoladun, A.C., Obutor, E.M. and Farombi, E.O. (2010) Evaluation of Antioxidant and Free Radical Scavenging Capacities of Some Nigerian Indigenous Medicinal Plants. Journal of Medicinal Food, 13, 444-451. http://dx.doi.org/10.1089/jmf.2008.0292

[31] Ejele, A.E., Duru, I.A., Ogukwe, C.E. and Iwu, I.C. (2012) Phytochemistry and Antimicrobial Potential of Basic Metabolites of Piper umbellatum, Piper guineense, Ocimum gratissimum and Newbouldia laevis Extracts. Journal of Emerging Trends in Engineering and Applied Sciences, 3, 309-314.

[32] Odunbaku, A.O. and Amusa, N.A. (2012) Antibacterial and Antifungal Effect of Ethanol Leaf Extract of Newbouldia laevis. Global Research Journal of Agricultural and Biological Sciences, 3, 370-372.

[33] Eyong, K.O., Folefoc, G.N., Kuete, V., Beng, V.P., Krohn, K., Hussain, H., Nkengfack, A.E., Saeftel, M., Sarite, S.R. and Hoerauf, A. (2006) Newbouldiaquinone A: A Naphtoquinone-Anthraquinone Ether Coupled Pigment as a Potential Antimicrobial and Antimalarial Agent from Newbouldia laevis. Phytochemistry, 67, 605-609. http://dx.doi.org/10.1016/j.phytochem.2005.12.019

[34] Amos, S., Binda, L., Vongtau, H., Chindo, B. and Abbah, J. (2002) Sedative Effects of the Methanolic Leaf Extract of Newbouldia laevis in Mice and Rats. Bollettino Chimico Farmaceutico, 141, 471-475.

[35] Akunyili, D.N. (2000) Anticonvulsant Activity of the Ethanol Extract of Newbouldia laevis. Proceedings of the 2nd NAAP Scientific Conference, Zaria, 2000, 155-158.

[36] Usman, H., Yaro, A.H. and Garba, M.M. (2008) Phytochemical and Anticonvulsant Screening of the Ethanolic Flower Extract of Newbouldia laevis (Bignoniaceae) in Mice. Journal of Pharmacology and Toxicology, 3, 127-133. http://dx.doi.org/10.3923/jpt.2008.127.133

[37] Tanko, Y., Kamba, B., Saleh, M.I., Musa, K.Y. and Mohammed, A. (2008) Anti-Nociceptive and Anti-Inflammatory Activities of Ethanolic Flower Extract of Newbouldia laevis in Mice and Rats. International Journal of Applied Research in Natural Products, 1, 13-19.

[38] Ainooson, G.K., Woode, E., Obiri, D.D. and Koffour, G.A. (2009) Antinociceptive Effects of Newbouldia laevis (P. Beauv) Stem Bark Extract in a Rat Model. Pharmacognosy Magazine, 5, 49-54.

[39] Kuete, V., Wabo, H.K., Eyon, K.O., Feussi, M.T., Wiench, B., Krusche, B. and Effert, T. (2011) Anticancer Activities of Six Selected Natural Compounds of Some Cameroonian Medicinal Plants. PLoS ONE, 6, e21762. http://dx.doi.org/10.1371/journal.pone.0021762

[40] Bafor, E., Sanni, U. and Nworgu, Z.A. (2010) In Vitro Determination of the Mechanism of the Uterine Stimulatory Effect of Newbouldia laevis. Pharmaceutical Biology, 48, 808-815. http://dx.doi.org/10.3109/13880200903283673

[41] Awemu, G.A., Okunrobo, L.O. and Awah, F.M. (2012) Wound Healing and Antiulcer Activities of the Ethanol Extract of Newbouldia laevis Root Bark. Journal of Pharmacy and Bioresources, 9, 29-33.

[42] Joppa, K.M., Vovor, A., Eklu-Gadegbeku, K., Agbonon, A., Aklikokou, K. and Gbeassor, M. (2008) Effect of Morinda lucida Benth. (Rubiaceae) and Newbouldia leavis P. Beauv. (Bignoniaceae) on Sickling of Red Blood Cells. Medecine Tropicale: Revue du Corps de Sante Colonial, 68, 251-256.

[43] Owolabi, O.J., Amaechina, F.C. and Okoro, M. (2011) Effect of Ethanol Leaf Extract of Newbouldia laevis on Blood Glucose Levels of Diabetic Rats. Tropical Journal of Pharmaceutical Research, 10, 249-254.

http://dx.doi.org/10.4314/tjpr.v10i3.12 
[44] Enye, J.C., Onubueze, D.P.M., Chineke, H.N. and Nweke, I. (2013) The Antihypertensive Property of Methanolic Extract of Newbouldia laevis on Anaesthesized Cats. Journal of Dental and Medical Sciences, 8, 35-39. http://dx.doi.org/10.9790/0853-0863539

[45] Olounlade, P.A., Azando, E.V.B., Hounzangbe-Adote, M.S., Tam-Ha, T.B., Leroy, E., Moulis, C., Fabre, N., Magnaval, J.F., Hoste, H. and Valentin, A. (2012) In Vitro Anthelmintic Activity of the Essential Oils of Zanthoxylum zanthoxyloides and Newbouldia laevis against Strongyloides ratti. Parasitology Research, 110, 1427-1433. http://dx.doi.org/10.1007/s00436-011-2645-4

[46] Ogungbite, O.C. and Oyeniyi, E.A. (2014) Newbouldia laevis (Seem) as an Enthomocide against Sitophilus oryzae and Sitophilus zeamais Infecting Maize Grain. Jordan Journal of Biological Sciences, 7, 49-55. http://dx.doi.org/10.12816/0008213

[47] Akerele, J.O., Ayinde, B.A. and Ngiagah, J. (2011) Phytochemical and Antibacterial Evaluations of the Stem Bark of Newbouldia laevis against Isolates from Infected Wounds and Eyes. Tropical Journal of Pharmaceutical Research, 10, 211-218. http://dx.doi.org/10.4314/tipr.v10i2.66566

[48] Onocha, P.A., Okorie, D.A., Krebs, H.C. and Meirer, B. (2011) In Vitro Cytotoxic Pentacyclic Triterpenoids of Newbouldia laevis. Research Journal of Medical Sciences, 5, 330-335.

[49] Anaduaka, E.G., Ogugua, V.N., Egba, S.I. and Akpe, V.O. (2013) Investigation of Some Important Phytochemical, Nutritional Properties and Toxicological Potentials of Ethanol Extracts of Newbouldia laevis Leaf and Stem. African Journal of Biotechnology, 12, 5941-5949.

[50] Anaduaka, E.G., Ogugua, V.N., Egba, S. and Apeh, V.O. (2013) Comparative Antidiabetic Effects of Ethanol Extracts of Newbouldia laevis Leaves and Stem on Serum Lipid Profile and Lipid Peroxidation Status in Alloxan Induced Diabetic Rats. World Journal of Pharmaceutical Sciences, 2, 833-845.

[51] Kolawole, O.T., Akanji, M.A., Awe, O.E. and Akiibinu, M.O. (2013) Ethanolic Extract of Leaves of Newbouldia laevis Attenuates Glycosylation of Hemoglobin and Lipid Peroxidation in Diabetic Rats. American Journal of Pharmacology and Toxicology, 8, 179-186. http://dx.doi.org/10.3844/ajptsp.2013.179.186

[52] Lorke, D. (1983) A New Approach to Acute Toxicity Testing. Archives of Toxicology, 54, 275-287. http://dx.doi.org/10.1007/BF01234480

[53] Akah, P.A., Alemji, J.A., Salawu, O.A., Okoye, T.C. and Offiah, N.V. (2009) Effects of Vernonia amygdalina on Biochemical and Haematological Parameters in Diabetic Rats. Asian Journal of Medical Sciences, 1, 108-113.

[54] Harborne, J.B. (1998) Phytochemical Methods. A Guide to Modern Technique of Plant Analysis. 3rd Edition, Chapman and Hill, London, 285.

[55] Frode, T.S. and Medeiros, Y.S. (2008) Animal Models to Test Drugs with Potential Antidiabetic Activity. Journal of Ethnopharmacology, 115, 173-183. http://dx.doi.org/10.1016/j.jep.2007.10.038

[56] Ezekwesili, C.N., Ogbunugafor, H.A. and Ezekwesili-Ofili, J.O. (2012) Antidiabetic Activity of Aqueous Extracts of Vitex doniana Leaves and Cinchona calisaya Bark in Alloxan-Induced Diabetic Rats. International Journal of Tropical Disease \& Health, 2, 290-300. http://dx.doi.org/10.9734/IJTDH/2012/1693

[57] Okoli, C.O., Ibiam, A.F., Ezike, A.C., Akah, P.A. and Okoye, T.C. (2009) Evaluation of Antidiabetic Potentials of Phyllanthus niruri in Alloxan Diabetic Rats. African Journal of Biotechnology, 9, 248-259.

[58] Nworu, C.S., Vin-Anuonye, T., Okonkwo, E.T., Oyeka, C.O., Okoli, U.B., Onyeto, C.A., Mbaoji, F.N., Nwabunike, I. and Akah, P.A. (2014) Unregulated Promotion and Sale of Herbal Remedies: A Safety and Efficacy Evaluation of Twelve Such Commercial Products Claimed to Be Beneficial and Patronized for a Variety of Ailments in Nigeria. Journal of Pharmacovigilance, S1, 002.

[59] Ernsberg, P. and Koletsky, R.J. (2012) The Glucose Tolerance Test as a Laboratory Tool with Clinical Implications. InTech Publisher, Rijeka.

[60] Daisy, P. and Rajathi, M. (2009) Hypoglycemic Effects of Clitoria ternatea Linn. (Fabaceae) in Alloxan-Induced Diabetes in Rats. Tropical Journal of Pharmaceutical Research, 8, 393-398. http://dx.doi.org/10.4314/tjpr.v8i5.48082

[61] Thirumurugan, K., Ankita, B.J. and Shihabuden, M.S. (2011) Screening of Fifteen Ayurvedic Plants for Alpha Glucosidase Inhibitory Activity and Enzyme Kinetics. International Journal of Pharmacy and Pharmaceutical Sciences, 3, 267-274.

[62] Bonora, E. and Muggeo, M. (2001) Postprandial Blood Glucose as a Risk Factor for Cardio-Vascular Disease in Type II Diabetes: The Epidemiological Evidence. Diabetologia, 44, 2107-2114. http://dx.doi.org/10.1007/s001250100020

[63] Verges, B. (2002) The Impact of Prandial Glucose Regulation in Practice. Diabetes, Nutrition \& Metabolism, 15, 2832.

[64] Jarald, E., Joshi, S.B. and Jain, D.C. (2008) Diabetes and Herbal Medicines. Iranian Journal of Pharmacology \& Therapeutics, 7, 97-106. 
[65] El-Abhar, H.S. and Schaalan, M. (2014) Phytotherapy in Diabetes: Review on Potential Mechanistic Perspectives. World Journal of Diabetes, 5, 176-197.

[66] Marles, R.J. and Farnsworth, N.R. (1994) Plants as Sources of Anti-Diabetic Agents. In: Wagner, H. and Farnsworth, N.R., Eds., Economic and Medicinal Plant Research, Academic Press Ltd., London, 149-187.

[67] Kolawole, O.T., Akanji, M.A. and Akiibinu, M.O. (2013) Toxicological Assessment of Ethanolic Extract of the Leaves of Newbouldia laevis (P. Beauv). American Journal of the Medical Sciences, 3, 74-80.

[68] Akah, P.A., Uzodinma, S.U. and Okolo, C.E. (2011) Antidiabetic Activity of Aqueous and Methanol Extract and Fractions of Gongronema latifolium (Aselepidaceae) Leaves in Alloxan Diabetic Rats. Journal of Applied Pharmaceutical Science, 1, 99-102.

[69] Ogunlana, O.E. and Ogunlana, O.O. (2008) In Vitro Assessment of Antioxidant Activity of Newbouldia laevis. Journal of Medicinal Plants Research, 2, 176-179.

[70] Ogunlana, O.E., Ogunlana, O. and Farombi, O.E. (2008) Assessment of Scavenging Activity of Crude Ethanolic Stem Bark Extract of Newbouldia laevis on Selected Free Radicals. Advances in Natural and Applied Science, 2, 249-254.

[71] Kambouche, N., Tadjeddine, A.L., Medjdoub, H., Dicko, A., Saidu, S. and Derdour, A. (2013) Antidiabetic Effect of Anacyclus valentinus L. Aqueous Extract in Normoglycemic and Streptozotocin Induced Diabetic Rats. American Journal of Phytomedicine and Clinical Therapeutics, 1, 424-423.

[72] Marles, R.J. and Farnsworth, N.R. (1995) Antidiabetic Plants and Their Active Constituents. Phytomedicine, 2, 133186. http://dx.doi.org/10.1016/S0944-7113(11)80059-0

[73] Warjeet, L.S. (2011) Traditional Medicinal Plants of Manipur as Antidiabetics. Journal of Medicinal Plants Research, 5, 677-687.

[74] Cazarolli, L.H., Zanatta, L., Alberton, E.H., Figueiredo, M.S., Folador, P., Damazio, R.G., Pizzolati, M.G. and Silva, F.R. (2008) Flavonoids: Cellular and Molecular Mechanism of Action in Glucose Homeostasis. Mini-Reviews in Medicinal Chemistry, 8, 1032-1038. http://dx.doi.org/10.2174/138955708785740580

[75] Pinent, M., Blay, M., Blade, M.C., Salvado, M.J., Arola, L. and Ardevol, A. (2004) Grape Seed-Derived Procyanidins Have an Antihyperglycemic Effect in Streptozocin-Induced Diabetic Rats and Insulinomimetic Activity in InsulinSensitive Cell Lines. Endocrinology, 145, 4985-4990. http://dx.doi.org/10.1210/en.2004-0764

[76] Goutam, B. (2011) Bioflavonoids with Promising Antidiabetic Potentials: A Critical Survey. In: Tiwari, V.K. and Mishra, B.B., Eds., Opportunity, Challenge and Scope of Natural Products in Medicinal Chemistry, Research Signpost, Trivandrum, 187-212.

[77] Kappel, V.D., Cazarolli, L.H., Pereira, D.F., Postal, B.G., Zomoner, A., Reginatto, F.H. and Silva, F.R. (2013) Involvement of GLUT-4 in the Stimulatory Effect of Rutin on Glucose Uptake in Rat Soleus Muscle. Journal of Pharmacy and Pharmacology, 65, 1176-1186. http://dx.doi.org/10.1111/jphp.12066

[78] Atta, E.M., Nassar, A.A., Hasan, N.M. and Hasan, A.R. (2013) New Flavonoid Glycosides and Pharmacological Activities of Pteranthus dichotomus Forssk. Records of Natural Products, 7, 69-79.

[79] Kumari, P., Khanam, S., Varma, M.C., Kumar, P., Chouhan, R. and Pandey, A.K. (2013) Study the Spirulina as a Potential Antidiabetic. Journal of Chemical, Biological and Physical Sciences, 3, 1963-1971.

[80] Shimizu, M., Kobayashi, Y., Suzuki, M., Miyamoto, Y. and Satsu, H. (2000) Regulation of Intestinal Glucose Transport by Tea Catechin. Biofactors, 13, 61-65. http://dx.doi.org/10.1002/biof.5520130111

[81] Pereira, D.F., Cazarolli, L.H., Lavado, C., Mengatto, V., Figueiredo, M.S., Guedes, A., Pizzolatti, M.G. and Silva, F.R. (2011) Effects of Flavonoids on Alpha Glucosidase Activity: Potential Targets for Glucose Homeostasis. Nutrition, 27, 1161-1167. http://dx.doi.org/10.1016/j.nut.2011.01.008

[82] Kolawole, O.T. and Akanji, M.A. (2013) Inhibitory Effect of Leaf Extract of Newbouldia laevis on the Metabolic Activities of Alpha-Glucosidase and Alpha-Amylase. Bangladesh Journal of Pharmacology, 8, 371-377. http://dx.doi.org/10.3329/bjp.v8i4.16422

[83] Nagappa, A.N., Thakurdesai, P.A., Rao, N.V. and Singh, J. (2003) Antidiabetic Activity of Terminalia catappa Linn Fruits. Journal of Ethnopharmacology, 88, 45-50. http://dx.doi.org/10.1016/S0378-8741(03)00208-3

[84] Eddouks, M. and Maghrani, M. (2004) Phlorizin-Like Effect of Fraxinus excelsiorin Normal and Diabetic Rats. Journal of Ethnopharmacology, 9, 149-154. http://dx.doi.org/10.1016/j.jep.2004.05.005

[85] Idris, I. and Donnelly, R. (2009) Sodium-Glucose Co-Transporter-2 Inhibitors: An Emerging New Class of Oral Antidiabetic Drug. Diabetes, Obesity and Metabolism, 11, 79-88. http://dx.doi.org/10.1111/j.1463-1326.2008.00982.x

[86] Katsuno, K., Fujimori, Y. and Takemura, Y. (2007) Serglifloxin, a Novel Selective Inhibitor of Low-Affinity Sodium Glucose Cotransporter (SGLT-2), Validates the Critical Role of SGLT-2 in Renal Glucose Reabsorption and Modulates Plasma Glucose Level. Journal of Pharmacology and Experimental Therapeutics, 320, 323-330. http://dx.doi.org/10.1124/jpet.106.110296 
[87] Meng, W., Ellsworth, B.A., Nirschl, A.A., McCann, P.J., Patel, M., Girotra, R.N., Wu, G., Sher, P.M., Morrison, E.P., Biller, S.A., Zahler, R., Deshpande, P.P., Pullockaran, A., Hagan, D.L., Morgan, N., Taylor, J.R., Obermeier, M.T., Humpherys, W.G., Khanna, A., Discenza, L., Robertson, J.G., Wang, A., Han, S., Wetterau, J.R., Janovitz, E.B., Flint, O.P., Whaley, J.M. and Washburn, W.N. (2008) Discovery of Dapagliflozin: A Potent, Selective Renal SodiumDependent Glucose co Transporter 2 (SGLT2) Inhibitor for the Treatment of Type 2 Diabetes. Journal of Medicinal Chemistry, 51, 1145-1149. http://dx.doi.org/10.1021/jm701272q

[88] Obute, G.C. and Adubor, G.O. (2007) Chemicals Detected in Plants Used for Folk Medicine in South Eastern Nigeria. Ethnobotanical Leaflets, 11, 173-194.

[89] Naidu, P.V.S., Kinthada, P.M.M.S., Kalyani, P. and Muralidhar, P. (2012) Characterization and Biological Activities of Quercetin Thiosemi-Carbazone Derivatives: Potential Anticancer Drugs. International Journal of Pharmacy and Biomedical Sciences, 3, 24-27.

[90] Graefe, E.U., Wittig, J., Mueller, S., Riethling, A., Uehleke, B., Drewelow, B., Pforte, H., Jacobasch, G., Derendorf, H. and Veit, M. (2001) Pharmaco-Kinetics and Bioavailability of Quercetin Glycolsides in Humans. Journal of Clinical Pharmacology, 41, 492-499. http://dx.doi.org/10.1177/00912700122010366

[91] Narender, T., Khaliq, T. and Madhur, G. (2011) Naturally Occurring Antihyperglycemic and Antidyslipidemic Agents. In: Tiwari, V.K. and Mishra, B.B., Eds., Opportunity, Challenge and Scope of Natural Products in Medicinal Chemistry, Research Signpost, Trivandrum, 155-185.

[92] Spasov, A.A., Maxeiner, M.P. and Bulanov, A.F. (2008) Antidiabetic Properties of Gymnema sylvestre. Pharmaceutical Chemistry Journal, 42, 626-629. http://dx.doi.org/10.1007/s11094-009-0195-1

[93] Liu, L., Deng, Y., Yu, S., Lu, S., Xie, L. and Liu, X. (2008) Berberine Attenuates Intestinal Disacharidase in Streptozotocin Induced Diabetic Rats. Pharmazie, 63, 384-388.

[94] Lu, S., Yu, Y., Zhu, H., Liu, X., Liu, L. and Liu, Y. (2009) Berberine Promotes Glucagon-Like Peptide-1 (7-36) Amide Secretion in Streptozotocin-Induced Diabetic Rats. Journal of Endocrinology, 200, 159-165. http://dx.doi.org/10.1677/JOE-08-0419

[95] Chattopadhyay, R.R. (1999) A Comparative Evaluation of Some Blood Sugar Lowering Agents of Plant Origin. Journal of Ethnopharmacology, 7, 367-372. http://dx.doi.org/10.1016/S0378-8741(99)00095-1

[96] Chempakam, B. (1993) Hypoglycemic Activity of Arecoline in Betel Nut (Areca catechu Linn). Indian Journal of Experimental Biology, 31, 474-475.

[97] Narender, S.S., Tiwari, P., Reddy, K.P., Khaliq, T., Prathipati, R., Puri, A., Srivastava, A.K., Chander, R., Agrawal, S.C. and Raj, K. (2007) Antidyslipidemic Agent from Aegle mormelos. Bioorganic \& Medicinal Chemistry Letters, 17, 1808-1811. http://dx.doi.org/10.1016/j.bmcl.2006.12.037

[98] Shah, S.N., Bodhankar, S.L., Ramesh, B. and Mohan, V. (2006) Hypoglycemic Activity of the Combination of Active Ingredients Isolated from Trigonella foenumgraecum in Alloxan-Induced Diabetic Mice. Pharmacology Online, 1, 6582.

[99] Nafisi, S., Asghari, M.H., Nezhadi, M.A. and Ekhatiari, M.S. (2011) Possible Antidiabetic Effect of Peganum harmala on Streptozocin-Induced Mouse. World Applied Sciences Journal, 14, 822-824.

[100] Singh, A.B., Chaturvedi, J.P., Narender, T. and Srivastava, A.K. (2008) Preliminary Studies on the Hypo-Glycemic Effect of Peganum harmala L. Seeds Ethanol Extract on Normal and Streptozotocin Induced Diabetic Rats. Indian Journal of Clinical Biochemistry, 23, 391-393. http://dx.doi.org/10.1007/s12291-008-0086-3 